\title{
COMMUNITY MEDIA ONLINE: RESEARCH APPROACHES AND PRACTICES OF FUNCTIONING (CASE OF ETHNIC MEDIA)
}

\author{
S. Korkonosenko ${ }^{1}$, M. Berezhnaia ${ }^{2}$ \\ St Petersburg State University, Russia \\ s.korkonosenko@spbu.ru ${ }^{1}$
}

Received 10/07/2017 - Accepted 27/09/2017

DOI: $10.15628 /$ holos.2017.6106

\begin{abstract}
The article considers conceptual approaches to community media studies. According to the authors, the dominant society centered and media centered approaches need to be clarified and in some cases revised. On the material of ethnic communities' digital media, the conclusion was done that the community centered approach may be relevant in this case, and
\end{abstract}

such an approach deserves special development in research. For empirical study, digital media of Russianspeaking communities were taken, 3 from Finland and 3 from Lebanon.

KEYWORDS: community media, society centered approach, media centered approach, digital communication, Russian-speaking communities. 


\section{INTRODUCTION}

Community media have become not only a developed and influential segment of media systems in the world and separate countries, but also the focus of scientific interest. There is a plenty of publications, including works that describe the diverse experience of media communities in various regions of the planet (Buckley, 2011; Howley, 2010; Johnson and Menichelli, 2006; Radcliffe, 2015; etc.). International and national associations contribute to the study and support of this type of media, for example: The Community Communication section in International Association for Media and Communication Research (IAMCR), The Community Media Forum Europe, Alliance for Community Media (USA) and so forth. Nevertheless, today the following statement is still true: "The concept of 'community media' has proved to be, in its long theoretical and empirical tradition, highly elusive" (Carpentier, Servaes and Lie, 2003, p. 51).

One of the key issues that need further consideration is the choice of a conceptual approach to media communities. Is it necessary to consider them mainly in the context of civic activity and the development of democracy, that is, in essence, from a sociopolitical viewpoint (society centered approach)? For example, in this way: "This dissertation explores the role of community media in democratic civil society governance through an examination of participatory communications" (Potter, 2014, p. ii). Or they should be evaluated mainly as a certain type of media sources focused on information support of closed communities thereby creating an alternative to the mainstream channels (media centered approach)? This approach is explicitly declared as an alternative to the civil viewpoint: "In the mass media age, mass communication researchers interested in civic engagement and participation focused primarily on media and media use. However ... the contemporary media environment calls for a focus on information received from media (and nonmedia sources), and whether that information meets communities' information needs" (Watson and Cavanah, 2015, p. 651).

Preliminary acquaintance with the practice of media communities raises doubts about the adequacy and effectiveness of any rigid research frame. In particular, it would be unacceptable while assessing the various examples presented at the international seminar "Journalism Communities: Experiences and Research in Russia, United States and Northern Europe", held at the St. Petersburg State University (March 10, 2015) (Korkonosenko, 2015). The seminar discussed the media resources of the communities which were formed in religious, ethnic, museum, territorial, immigrant and other environments, that is, they do not fit into any strict conceptual and structural framework. Of course, such particular observations cannot pretend on theoretical generalizations, they occur at the pre-theory level. The pre-theory reflects the initial views of a scientist, formed on the basis of a preliminary acquaintance with the object. It always has a place in the cognitive process, and gives impetus to a purposeful research searching. In our case, pre-theoretical observations serve as an incentive to formulate a problem issue, construct hypotheses, and then analyze empirical data.

\section{RESEARCH PROBLEM AND HYPOTHESES}

Epistemologically, the problem is that the sociological way of thinking comes into conflict with the real features of the object, namely communities' media. Researchers a priori burden all media resources of communities with explicit social intentions, including civic activism. The experience and methodology of analysis of traditional mass media are transferred to them. However, 
community media are objects of different kinds, internally heterogeneous in essence and widely diverse in the forms in which it appears to the outside world.

The choice of forms depends on the staff qualification - from professional journalists (closer to traditional media) to amateurs-volunteers (closer to informal communication). Diversity of content and forms has come with the use of digital and network technologies by communities. The digital space is free from typological standards that determine the traditional media design and, accordingly, the parameters for their research. The institutionalized media hierarchy has been replaced by poorly structured information streams, intermixed with each other. This effect has been exactly described: "Although previously, some modes of communication mediated interpersonal networks (talking face-to-face, mail, telephone) and different ones spanned mass audiences (radio, newspapers, TV), now - thanks to digital code and Internet technologies virtually any communication of any social scope can commingle over the same wires and airwaves, using the same protocols and standards. What is good for the big is good for the small, and good for the medium-sized as well" (Kelly, 2008, p. 3). In our opinion, this general characteristic should be taken into account when assessing the activities of community media on digital platforms.

In contradiction to popular theoretical approaches, the main hypothesis is that digital community media are not so much media organizations with precisely defined functional coordinates, but mostly a communicative space that is flexible in purpose, content and ways of functioning. Additional hypothesis: the degree and forms of social and civic activity of community media depend on the real conditions of existence and needs of the communities which are initiators and participants in media communication. Thus, the study of media created by real communities will be more efficient from theoretical and methodological positions (media of communities, or community media, in widespread tradition) than of communities formed on the basis of media (media based communities). Indeed, in the reality the needs, interests, motives that lead to the creation of media predetermine the ways of their functioning.

The purpose of this article is to verify hypotheses during the analysis of the activity of specific media communities in relation to various theoretical approaches to their understanding and classification.

\section{THEORETICAL APPROACHES}

There are fruitful attempts to overcome the narrow framework of researching media community through the prism of media, social and civic activity. The solution was proposed through the definition of their identity as a soft and mobile substance: "Both their embeddedness in a fluid civil society (as part of a larger network) and their antagonistic relationship towards the state and the market (as alternative to mainstream public and commercial media) make the identity of community media highly elusive. In this approach it is argued that this elusiveness and contingency, as is the case for a rhizome, forms its main defining element" (Carpentier, Servaes and Lie, 2003, p. 61). However, civic participation and democracy remained the main reference sphere for the authors of the cited article.

A clear division of community media into those of a civil nature and those who avoid socially significant issues was suggested by A. Pavlov. He took as a basis the distinction between "neighbor" and "civil" community media, which correspond to different types of online publics (2016, p. 48). In this respect, he is a follower of D. Walker, who first substantiated such a binary classification code (2011). On the empirical basis of the Moscow districts communities' networks Pavlov showed, that "the 'neighbor' regime of local communication differs from the 'citizen' one not only by more 
private issues to be discussed ... but also by a special emotional aura 'of the neighborhood' that is meaningful to its participants". At the same time, in analyzed groups, none of the regimes of communication was detected in pure form, because each of them includes mixed forms of the discursive participation (Pavlov, 2016, p. 55).

1.1.1 In connection with this study it is necessary to mention one more conservative interpretation of community media, when they are treated as mostly local ones. "Community media are created primarily with and by residents of a specific geographic place," as the U.S. analysts argue (Johnson and Menichelli, 2006, p. 3). "Community media is essentially used to promote community communication among members of the local community," the Japanese author adds (Kanayama, 2007, p. 8).

Meanwhile, nowadays there is a rethinking of merely geographical interpretation of community media. First of all, the diversity of the communities themselves requires the variability of the interpretations. Such is the logic of the authors of the chapter "Various forms of community media" in a collective online manual: "If we want to make the typology even more extensive, we might distinguish several different types of communities: • Local community ... • Community of interests ... Ethnic community: people with shared ethnic background but living scattered in different parts of the country or world, in so called 'diaspora'. • Ideological community ..." (Alternative and Community Media). The following definition corresponds to the approach, mentioned above: "Community media are a broad category of media structures across different technological platforms ... operated for and by ... a community (... of interest, a geographical community, or a cultural community) and are characterized by the effective participation of that community in all processes of the organization" (Coyer and Hintz, 2010, p. 276). It should be added that the use of ICT dictates to consider all sorts of extraterritorial community media, at least on a par with territorial ones.

In the reference to the online manual, the case of ethnic communities is described which can be local (within a small territory) as well as cross-border. They provide especially representative material for community media functioning study, including the aspect of their division into "neighbor" and "civil". It seems, the key to define community media orientation is in the motives for their creation, which, in turn, are derived from the nature of the communities and their needs for information exchange. This interrelation was revealed in the study of ethnic network media in the Russian regions (Gladkova, 2015). We will attempt to carry out analysis on the material of diasporal media in other countries.

\section{METHODOLOGY}

For the analysis ethnic communities were taken, for which value of the common identity is stressed by the existence in a foreign social and cultural environment. The object of the study includes the Russian-speaking diasporas' community media in Finland and Lebanon. Their declared aims are to preserve Russian culture and language, help immigrants to adapt, strengthen ties between Russia and the host country; all of them have permanent open groups in social networks. The community media functioning was regarded in correlation with the communities' existence conditions. According to Human Development Report 2016, Finland has the 23 place in the rank while Lebanon has 76 among 188 countries (2016, p. 198-199). Experts also register different levels of Quality of Nationality Index (QNI) in these countries: 2015 Rankings shows the 3 place for Finland and 131 for Lebanon (Quality of Nationality Index, 2015). 
The final sample included 3 communities from Finland and 3 from Lebanon; the study period was 6 months (from September 1, 2016 to March 1, 2017). For assessing the content and directions of communication activity in the Facebook, the content analysis method has been used, in combination with the case study. The analysis took into account all news publications at communities' Facebook pages.

Parameters of analysis include:

- Messages types: information (informing on planned events, competitions, training programs and seminars, announcements, congratulations), reporting (demonstration of activities' results, photos, video of events), education (articles, interviews and other publications not related to community activities, but having a broader political, social or cultural context); publications on public-civic topics were registered separately;

- Intensity of activities: the range of participants, the frequency of the news update and extension, the use of different channels of communication in addition to the mainstream media;

- Targeting: inward / outward communities, the language of messages as an indicator of the addressee of communication.

\section{DATA DESCRIPTION AND ANALYSIS}

\subsection{Media of Russian-speaking communities in Finland}

The Russian Diaspora in Finland is represented on the network by three unifying platforms: the Information Portal for Compatriots in Finland (http://mosaiikki.info), Finnish Association of Russianspeaking Communities (FARO) (http://faro.fi/ru/) and the site "Russian-speaking in Finland" (http://www.svkeskus.fi/). As the "umbrella" organization the Finnish Association of Russianspeaking Societies (FARO) operates, on the basis of which the Coordinating Council of Russian Compatriots was created in Finland in 2007. In 2013, it was renamed the All-Finland Union of Organizations of Russian Compatriots (OSORS), which currently includes representatives of about 40 Russian-speaking organizations, but on the site (http://osors.fi), and also on the portal (http://mosaiikki.info) there is no complete list, not all links are active, there is no access to the network pages of organizations (March 2017).

As an agglomeration of communities, as a matter of fact, the "community of communities" OSORS correlates its activities with the World Coordinating Council of Russian Compatriots Living Abroad, its website and social network pages (Facebook and VKontakte) provides a variety of information on the work of similar organizations around the world. This association is not considered a community in our research.

The activities of the FARO are aimed at protecting the rights, social and cultural interests of Russian-speaking population and at cooperation and promotion of Russian-speaking organizations' initiatives within the framework of the Finnish legislation.

The FARO programs cover collecting and disseminating information on social activities in Finland, multilingual families in Finland, the experience of adaptation and protection of children's rights, the collaboration with social services, elections and possibilities to participate in public activities, as well as information on youth programs, employment programs, entrepreneurship, bilingual cultural projects and the Russian-language blogosphere. Via the website one can access the sites and network addresses of its members. For each area of activity, references are made to the relevant resources, documents, and publications in the media. Thus, the activity of FARO as a whole is oriented on the interests of the target group. The deputy chairman of the FARO, Svetlana Ranta 
notes in the article "Integration Is a Two-way Process", that over 20 years as she lives in Finland, the attitude of Finnish society towards the Russians has changed significantly. There are effective courses in teaching Finnish language and computer literacy, news in Russian on TV, programs with the participation of Russian immigrants and settlers. This is due not only to Finland's accession to the European Union, but also to the activities of public organizations aimed at overcoming the Finnish people apprehension to a foreign culture (Pertseva, 2016a).

However, there is a problem field for the Russian-speaking diaspora in Finland; the problems were outlined at the conference held by the Cultura Foundation in October 2016. In Finland, European media researchers exchanged experience in studying the media and media consumption of Russian-speaking Europeans. According to the FARO information coordinator Tatyana Pertseva, the Russian-speaking society of Finland is fragmented by silence, which will be broken when "the hidden social issues concerning Russian-speaking ... will be considered in the dialogue between experts, the community itself, and researchers of transnational media processes" (Pertseva, 2016b).

FARO is rather inactive in networks: there are 392 participants in Facebook group, 61 readers on Twitter, and 42 in Instagram. On the Association's website, there are references to 41 organizations, of which 9 links are currently inactive (March 2017), thus 32 organizations were included in the primary list of the study. The sample consists of organizations declaring on their websites the promotion of the social and cultural interests of the Russian-speaking diaspora in Finland; sampling did not include organizations that provide mainly commercial services (educational, concert activities, advertising agencies, video production companies, etc.), as well as literary clubs and art associations, children's, sports and health clubs.

It may be seen (Table 1) that the communities are presented online unevenly: each organization has a website, but there are little network communities. Facebook is a preferable social net.

\begin{tabular}{|c|c|c|c|c|}
\hline Community & Web site & Facebook page & VKontakte page & Other net pages \\
\hline $\begin{array}{c}\text { The Russian Cultural- } \\
\text { Democratic Union }\end{array}$ & + & 0 & 0 & 0 \\
\hline $\begin{array}{c}\text { Центр русской культуры } \\
\text { в г. Тампере }\end{array}$ & + & + & + & $\begin{array}{c}\text { Odnoklassniki, } \\
\text { Twitter }\end{array}$ \\
\hline $\begin{array}{c}\text { Center of Russian } \\
\text { Culture in Tampere }\end{array}$ & + & + & 0 & 0 \\
\hline Cultural Bridge & + & + & 0 & 0 \\
\hline
\end{tabular}

Table 1. Russian-speaking communities online, Finland.

The Russian Cultural-Democratic Union, which began its activity in 1945 from the schools of Russian literacy, the Russian lyceum and publishing, currently unites several creative collectives, 
organizes concerts and festivals, but is not represented in the communicative field online. The site of the organization is updated from one event to another with large time intervals.

Facebook pages as common media for the other FARO communities within sampling were compared with each other according to the research parameters (Table 2).

\begin{tabular}{|c|c|c|c|c|c|c|c|}
\hline \multirow{3}{*}{ Community } & \multicolumn{7}{|c|}{ Messages } \\
\hline & \multirow{2}{*}{$\begin{array}{l}\text { Number of } \\
\text { messages }\end{array}$} & \multicolumn{3}{|c|}{ Messages type } & \multirow{2}{*}{$\begin{array}{l}\text { Language } \\
\text { (Russian / } \\
\text { Finnish) }\end{array}$} & \multirow{2}{*}{$\begin{array}{l}\text { Civic } \\
\text { topics }\end{array}$} & \multirow{2}{*}{$\begin{array}{c}\text { Group } \\
\text { members }\end{array}$} \\
\hline & & Information & Reports & Education & & & \\
\hline $\begin{array}{l}\text { Center of } \\
\text { Russian Culture } \\
\text { in Tampere }\end{array}$ & 72 & 59 & 12 & 1 & $71 / 4$ & 10 & 143 \\
\hline $\begin{array}{l}\text { Russian Club in } \\
\text { Tampere }\end{array}$ & 67 & 62 & 4 & 1 & $65 / 6$ & 8 & 365 \\
\hline Cultural Bridge & 75 & 37 & 35 & 2 & $72 / 14$ & 2 & 144 \\
\hline
\end{tabular}

Table 2. Russian speaking communities' activities in Facebook, Finland.

Generally all communities have approximately the same intensity of updates, an average 3 times a week; the messages mainly are defined as information and reports, the civic topics appear rarely, they are not a significant subject of online discussions. The main addressee are members of the community as communication happens mainly in Russian, thus we are dealing with inward communication. Additional observations: in network communication feedback is poorly represented, the question-answer form prevails, and there are no meaningful comments and discussions.

At the same time, the content of web pages demonstrates some differences in the activities of communities' media.

Center of Russian Culture in Tampere. During the research period the main messages topics were: the literary festival Aurora Borealis in Tampere and the 73rd anniversary of the complete lifting of the siege of Leningrad. The current information was dedicated to travel, concerts, Christmas events and free seminars, there were announcements about issuing certificates to pensioners, a whiskey testing party, private lessons, etc. There are 142 "likes" for the entire period of the page existence. Information on the events is also delivered by the organization via regular and electronic mail.

An important message, connected with the problems of human rights and democracy, was the Ossi Mansikka's article "The Large and Powerful Minority - the Number of Russian-speaking Residents in Finland Increases", which appeared in "Helsingin Sanomat" (Mansikka, 2016). The author poses the problem of the Russian-speaking population's integration into Finnish society and indicates that Russian-speakers can become a politically active group soon. The announcement of "Two citizenships survey" conducted by "Russian-speaking in Finland" in February 2017 was also important. This survey was a response to the published results of a general poll by the Taloustutkimus research company commissioned by Yle: $66 \%$ of respondents stated that two citizenships persons should not hold positions in the Defense Forces and the Foreign Ministry, as they represent a threat to national security. The current Constitution and the laws of Finland 
prohibit refuse the applicant for a job because of dual citizenship. "Russian-speaking in Finland" promised to present the results of the new survey on the Finnish version of its website and to transfer them to the advisory council on ethnic issues under the Ministry of Justice of Finland.

The Russian Club in Tampere is a public non-profit organization that unites the Russian-speaking population of Tampere and the Pirkanmaa region in Finland. The organization has a website with a variety of menus, in particular, there are sections "Bulletin board" - about services and work; "Encyclopedia" - short articles on various topics, such as historical anecdotes, the origin of words, the psychology of relations; "It's interesting" - advice on landscape design, or how to choose a gift to the boss, or how to make life happy, etc.

The organization is active in the network (414 likes on the page; for reference, the Russian diaspora in Tampere joins 400 people). In addition to traditional publications related to cultural events and holidays, the community publishes information on activities for immigrants, about social benefits, parliamentary decisions on changing assistance to the unemployed, the consulate work, and on the School for electorate.

There were several messages focused on civic participation. Among them was invitation to a meeting with a lawyer (September 13, 2016), who, how it was written in the text, "could protect the rights of the Russian-speaking population in the parliament if he becomes a deputy". It was planned to discuss social and economic problems in Finland during the meeting. The organizer Margarita Niemi wrote, responding to a lonely question: "Of course, I understand that our civic activity is not very high, and yet... There is an opportunity to meet with a professional, provided legal assistance to many of us. But he will not come without preliminary applications." The meeting did not take place because of the lack of people. There was also invitation to a meeting related to the local elections in Tampere. Announcement appeared twice: for the first time as a usual information text, and in the second case as a persistent appeal, apparently caused by the lack of participants: "The people! Who has a free evening? Come. Show civil initiative!"

Cultural Bridge is aimed at supporting Russian-speaking immigrants in the process of adaptation to Finnish society through immersion in creativity, folk culture and art (Mantere). According to the page, the main events during the 6 months were a charity festival "Dari-good", the broadcast of the International Video Poetry Project "My Poet", Tilde dolls master-classes; these were events where group members participated and took part in online voting. There was also information about celebrations such holidays as Christmas, Maslenitsa, Independence Day of Finland, as well as news and reports about the conversation group and excursions in Russian, the work of the career planning and social counseling center, the initiative group of the Immortal Regiment in Helsinki, the VII Congress Finno-Ugric peoples, Total dictation, etc.

The total number of "likes" is 139. It should be noted that a significant number of announcements were written in Finnish, as well as of events designed for the participation of Finnish citizens, so we meet the outward communication in this case. The group actively shows its work, uploads photos and video of events, information is accompanied by introductory articles of the moderator.

The Russian-speaking in Finland organization, in turn, declares support for the culture and traditions of the Russian-speaking population of Finland and focuses on integration activities: "SVK unites active Russian-speaking people living in Finland. We understand the necessity and timeliness of creating a network of 'positive contacts'. Our activities are based on the principles of conflictfree communication. Any questions are resolved in a positive manner" (Organization).

The topics on the organization's website closely correlate with these tasks: employment, taxation, pension issues, social brochures on various aspects of the arrangement in Finland, Finnish- 
Russian colloquial meetings, career planning. There are links to relevant sites and addresses for each topic. It was this organization that initiated its own alternative survey of two citizenships. Facebook page is inactive. The site contains a list of 4 partner organizations, but not all links are active also. One of the partners - Klubok ry - was created to support Russian families in the metropolitan region. The club is eager to create a network of acquaintances for communication, mutual assistance, support, for the self-development of each member of the family. Klubok does not have a network group, but it organizes weekly meetings.

Despite the formal interaction of the majority of Russian-speaking communities with OSORS, none of the pages mentioned the significant all-national conference "Russian Culture in Finland" (Helsinki, November 15, 2014) in resolution of which there was done evaluation of the activities of compatriots' organizations and strategic directions were outlined. There was also no reaction on the airplane crash on December 25, 2016, in connection with which the Russian ambassador canceled the reception; there were no discussions on the dismantling of the memorial plaque to Finnish General Mannerheim in St. Petersburg, etc.

\subsection{Russian-speaking communities' media in Lebanon}

The communities of the Russian diaspora in Lebanon are united around the Russian Center for Science and Culture (RCSC), which is the representative of Rossotrudnichestvo - the Federal Agency for the Commonwealth of Independent States, compatriots living abroad, and for international humanitarian cooperation, under the Ministry of Foreign Affairs of Russia (Rossiisky Centr...). The RCSC is represented in all major Internet networks and youtube. On the site of the Center there is a list of the Coordinating Council of Russian Compatriots in Lebanon (CSL) and a list of partner organizations, but there are no links to their pages in the networks. The Charter of the CSL, also presented on the website of the RCSC, says that it was established to coordinate the activities of public organizations of compatriots - associations and clubs of graduates and the Society of Lebanese-Russian Friendship. The Council works closely with the Embassy and the Mission of Rossotrudnichestvo (Ustav Koordinacionnogo Soveta...).

The affiliation of the Lebanese Russian-speaking communities with the state structures of Russia is reflected in the content of their pages in social networks. Facebook pages of three organizations were taken for comparison how in the previous case (Table 3).

\begin{tabular}{|c|c|c|c|c|c|c|c|}
\hline \multirow{3}{*}{ Community } & \multicolumn{6}{|c|}{ Messages } & \multirow{3}{*}{$\begin{array}{l}\text { Group } \\
\text { members }\end{array}$} \\
\hline & \multirow{2}{*}{$\begin{array}{l}\text { Number of } \\
\text { messages }\end{array}$} & \multicolumn{3}{|c|}{ Messages type } & \multirow{2}{*}{$\begin{array}{c}\text { Language } \\
\text { (Russian/English/ } \\
\text { Arabic/Chinese) }\end{array}$} & \multirow{2}{*}{ Civic topics } & \\
\hline & & Information & Reports & Education & & & \\
\hline CARYL & 39 & 27 & 11 & 1 & $17 / 15 / 4 / 1$ & 15 & 769 \\
\hline $\begin{array}{l}\text { Club Rodina } \\
\text { in Lebanon }\end{array}$ & 85 & 54 & 20 & 4 & $78 / 13 / 0 / 0$ & 7 & 516 \\
\hline $\begin{array}{l}\text { Graduates } \\
\text { of Lebanon }\end{array}$ & 23 & 7 & 16 & 0 & $72 / 0 / 14 / 0$ & 0 & 2631 \\
\hline
\end{tabular}

Table 3. Russian speaking communities' activities in Facebook, Lebanon. 
As may be seen from Table 3, the communities have different update rates, but this does not affect the number of participants in groups. It should also be noted that communities conduct their pages not only in Russian, but also in English and Arabic (and even in Chinese), targeting information to a multinational audience; this practice should be defined as outward communication.

CARYL (Cultural Association of Russian-speaking Youth in Lebanon) declares such tasks: facilitating and strengthening friendship and cooperation between Russian and Lebanese youth associations with similar goals; uniting Russian-speaking youth in Lebanon and in other countries; organizing joint ventures, exchanging delegations, and conducting joint festivities (CARYL). Events and news on the page are correlated with the similar news of the Russian Cultural Center: activities of the Civic Center, youth projects, the "Living Classics" contest, information about the World Festival of Youth and Students; there are also announcements about language courses, concerts and celebrations. For the great contribution to the patriotic education of youth, the organization was awarded with the Certificate of CSL.

The Club Rodina in Lebanon community page also presents events held at the RCSC: the militarypatriotic game "Battle for Moscow", the competition of young readers, Tatyana's Day, information on educational programs in Russia, cultural events, fairs, etc. Also the page publishes modern Russian fairy tales.

Civil initiative of help to the victims in Syria deserves special attention. The organizers wrote: "Dear compatriots and colleagues! On the initiative of a woman from Belarus Natalia, the owner of a small Natasha food store in Beirut, and with the support of RCSC, the CSSL and the Rodina association, an action was launched to collect assistance for our compatriots in the war zone in Syria. <...> And our help is very necessary! There are a lot of widows in Aleppo, and they are left alone with their children. This is not an appeal, but just a story about how a small initiative can become an important and necessary for everybody!!!" (September 29, 2016). The unanimity of Russian compatriots in Lebanon manifested itself in the common statement (June 2014) on the situation in Ukraine, in which the violations of the rights of people and military actions in the Donbas were strongly condemned. No community in Finland has spoken on this painful issue of international life.

The community page of Graduates of Lebanon (Association of Russian and Soviet universities' graduates) has in total 2649 "likes". Meanwhile, its updating occurs at monthly intervals, and it contents not so much information messages as reports on events that have already taken place. The unifying idea for the Alumni Association is the value of education in Russia for members of this community. Accordingly, it is this idea that is being promoted through media channels, and its support by graduates of Russian universities is the cause of activity on the Web.

\section{CONCLUSIONS}

Community media operate as important additional informational, communicative and organizational resources for the real ethnic communities in Finland and Lebanon.

The Finnish society provides immigrants good opportunities of adaptation to different social environment. Respectively, community media in Finland show adaptive motivation of communities' activities. This motivation is articulated as the goal of organizations in evaluation of their activities; it may be revealed in the availability of social resources links and in the character of information that promotes the integration of communities into Finnish society, in supporting interpersonal horizontal connections within communities, and in specific problematic messages about obstacles 
to such integration. Such intentions are particularly evident against the background of some distance from explicit cooperation with OSORS and the World Coordinating Council of Russian compatriots living abroad, associated with the state structures of the Russian Federation. Communication of these communities can be described mostly as inward: news are written predominantly in Russian, the information is aimed at involving Finnish citizens who are interested in the Russian language, in community's activities, and there is a lot of information about the adaptive capabilities of the host country.

In Lebanon, Russian immigrants live in relative isolation from the unusual social and cultural environment. Therefore, Russian-speaking communities are more focused on communication with the motherland, promotion of the values of Russian culture, educational programs in Russia, and civil participation in international projects of Russia. The patriotic orientation of the communities' activities is also explained by the political situation in the region, which makes one to count on assistance and protection from Russia in extreme situations. The outward direction of communication is explicitly expressed, namely, in the multilingualism of news, the availability of publicly important information, the demonstration of Russia's achievements; communities present themselves as representatives of the country.

Thus, the hypothesis that the current reality determinedly influents the community media activity was confirmed. Our first hypothesis was also confirmed. The communities' network resources have little resemblance to "classical" media, since they operate primarily as informal space for communication which looks flexible in purpose, content and ways of functioning.

From another side, by the tone and manner of communication the communities' network resources are similar to the corporate media, which are designed for people of narrow circle for strengthening the spirit of unity. The content reflects the diverse offline activities of the communities, which are represented on the network mainly in a positive way, mostly out-of civic participation topics and problem interpretation of events. Such a strategy leads to the community internal integration through the creation of an atmosphere of accord and cohesion.

In this regard, may be suggested the conclusion of a methodological nature. In theory and methodology neither the media centered approach works, nor the social centered approach, as we expected when formulating hypotheses. In relate to the studied ethnic network resources the special community centered approach will be relevant, and this methodology deserves detailed development in research practice.

\section{REFERENCES}

ALTERNATIVE and Community Media. Various Forms of Community Media. Retrieved from: http://www2.amk.fi/digma.fi/eetu/www.amk.fi/opintojaksot/0702010/1204871263088/120487 1755653/1204871860182/1204874765272.html.

BUCKLEY, S. (Ed.) (2011). Community Media: a Good Practice Handbook. Paris: UNESCO.

CARPENTIER, N., SERVAES, J. and LIE, R. (2003). Community Media: Muting the Democratic Media Discourse. Continuum, n. 17(1), p. 51-68. doi: 10.1080/1030431022000049010.

CARYL - Cultural Association of Russian-speaking Youth in Lebanon. Retrieved from: https://www.facebook.com/groups/oleg.farah/.

COYER, K. and HINTZ, A. (2010). Developing the "Third Sector": Community Media Policies in Europe. In: B. Klimkiewicz (Ed.). Media Freedom and Pluralism: Media Policy Challenges in the Enlarged Europe. Budapest: CEU Press, p. 275-297. Retrieved from: http://books.openedition.org/ceup/2186. 
GLADKOVA, A. A. (2015). Regional'nye Veb-saity Etnicheskih Grupp Rossii kak Otrazhenie Yazykovogo i Kul'turnogo Plyuralizma v Seti Internet (Russia Ethnic Groups' Websites as a Reflection of Linguistic and Cultural Pluralism in the Web). Vestnik Moskovskogo universiteta, seriya 10, Zhurnalistika

(Bulletin of

the Moscow State University, series 10, Journalism), n. 2, p. 17-39 (in Russian).

HOWLEY, K. (Ed.) (2010). Understanding Community Media. Los Angeles and London: Sage.

HUMAN Development Report (2016). Washington DC: Communications Development Incorporated.

JOHNSON, F. and MENICHELLI, K. (2006). What's Going on in Community Media. Washington: Benton Foundation.

KANAYAMA, T. (2007). Community Ties and Revitalization: The Role of Community Radio in Japan. Keio Communication Review, n. 29, p. 5-24.

KELLY, J. (2008). Pride of Place: Mainstream Media and the Networked Public Sphere. Cambridge: Berkman Center for Internet and Society at Harvard University.

KORKONOSENKO, S. (Ed.) (2015). Zhurnalistika Soobshestv: Opyt i Nauchnye Issledovaniya v Rossii, SShA, Severnoy Evrope (Journalism of Communities: Experiences and Researches in Russia, United States and Northern Europe). St. Petersburg: St. Petersburg State University, Philological Faculty (in Russian).

MANSIKKA, O. (2016). Bol'shoe i Mogushestvennoe Men'shinstvo-Chislo Russkoyazychnyh Zhitelei Finlyandii Uvelichivaetsya (The Large and Powerful Minority - the Number of Russianspeaking Residents in Finland Increases). Helsingin Sanomat, October 4. Retrieved from: http://inosmi.ru/social/20161004/237968357.html (in Russian).

MANTERE, A. O nas (About Us). Retrieved from: http://kulsi.fi/o-nas/ (in Russian).

ORGANIZACIYA (Organization). Retrieved from: http://www.svkeskus.fi/organizatsiya (in Russian).

PAVLOV, A. V. (2016). Lokal'nye Gorodskie Soobshestva v Social'nyh Setyah: Mezhdu "Sosedskoi" i "Grazhdanskoi" kommunikaciei (Local City Communities in Social Networks: Between "Neighbor" and "Civil" Communication). Labirint. Zhurnal social'no-gumanitarnyh issledovaniy (Labyrinth. Journal of Philosophy and Social Sciences), n. 5, p. 46-57 (in Russian).

PERTSEVA, T. (2016a). Stat'ya Svetlany Ranty v Gazete "Etelä-Saimaa": Integraciya - Process Dvustoronniy (Article by Svetlana Ranta in the "Etelä-Saimaa" Newspaper: Integration Is a Twoway Process). Retrieved from: http://faro.fi/ru/статья-светланы-ранты-в-газете-etela-saimaa12-12-2016-ин (in Russian).

PERTSEVA, T. (2016b). Russkoyazychnoe Soobshestvo Finlyandii Razdrobleno Molchaniem (The Russian-speaking Community in Finland Is Fragmented Because of Silence). Retrieved from: http://faro.fi/ru/\%D1\%80\%D1\%83\%D1\%81\%D1\%81\%D0\%BA\%D0\%BE\%D1\%8F\%D0\%B7\%D1\%8B \%D1\%87\%D0\%BD\%D0\%BE\%D0\%B5-

\%D1\%81\%D0\%BE\%D0\%BE\%D0\%B1\%D1\%89\%D0\%B5\%D1\%81\%D1\%82\%D0\%B2\%D0\%BE-

\%D1\%84\%D0\%B8\%D0\%BD\%D0\%BB\%D1\%8F\%D0\%BD\%D0\%B4\%D0\%B8\%D0\%B8/ (in Russian).

POTTER, R. (2014). Community Media and Civil Society: Lessons from the Bolivarian Republic of Venezuela. Ph.D Dissertation. Urbana (Illinois).

QUALITY of Nationality Index. Retrieved from: https://nationalityindex.com/\#.

RADCLIFFE, D. (2015). Where Are We Now? UK Hyperlocal Media and Community Journalism in 2015. Cardiff: Centre for Community Journalism (C4CJ) at Cardiff University.

ROSSIISKY Centr Nauki i Kul'tury $v$ Beirute (RUSSIAN Centre of Science and Culture in Beirut). Retrieved from: http://www.rcnklebanon.com/russian-compatriots-lebanon (in Russian). USTAV Koordinacionnogo Soveta Rossiiskih Sootechestvennikov v Livane (The Charter of the Coordination Council of Russian Compatriots in Lebanon). Retrieved from: http://media.wix.com/ugd/acf72e_33f57e85ed11414e9a4bf02b045b98c5.pdf (in Russian).

WALKER, D. M. (2011). Networked Public Talk: Attention, Difference, and Imagination in Online Urban Forums. Ph.D Dissertation. University of Michigan.

WATSON, B. R. and CAVANAH, S. (2015). Community Information Needs: a Theory and Methodological Framework. Mass Communication and Society, n. 18(5), p. 651-673. doi: 10.1080/15205436.2015.1059948. 